\title{
ÚSKALÍ POUŽITÍ ZÁSADY IURA NOVIT CURIA V MEZINÁRODNÍM ROZHODČÍM ŘÍZENÍ
}

\author{
FRANTIŠEK HALFAR
}

\begin{abstract}
The Perils of Application of the Iura novit curia Principle in International Arbitration The article discusses the practicability of application of the iura novit curia principle in international arbitration and the potential problems arising thereof. The procedural principle governing most civil-law jurisdictions concerns the arbitrator's power to assess the merits of the case independently of the arguments of the parties and to ascertain and apply the law on its own motion. In arbitration, the application of the principle raises a number of concerns, such as due process, party autonomy or the protection of the interests and expectations of the parties, and touches upon the basic understanding of the arbitrator's mandate. Thus, the article analyses the principle in light of the theoretical doctrines and fundamental principles of international arbitration.
\end{abstract}

Keywords: arbitration; iura novit curia; treatment of applicable law; due process; party autonomy; equal treatment; surprising arbitral award; enforceability of arbitral award; arbitration doctrines

Klíčová slova: rozhodči rízení; iura novit curia; zacházení s rozhodným právem; řádný proces; autonomie stran; rovné zacházení; překvapivost rozhodčího nálezu; vykonatelnost rozhodčího nálezu; doktríny rozhodčího řízení

DOI: $10.14712 / 23366478.2019 .14$

\section{1. ÚVOD}

Základní úkol a podstata mandátu rozhodce spočívá v projednání a rozhodnutí sporu, který mu předložily strany na základě své rozhodčí smlouvy. Rozhodce tedy obdobně jako soudce projednává podání stran a následně vydává nestranné, odůvodněné (ledaže to vyloučí strany) ${ }^{1}$ a závazné rozhodnutí, které konkluzivně (nabývá účinku res iudicata) stanovuje práva a povinnosti stran. Tato quasi-soudní funkce činnosti rozhodce předpokládá povinnost rozhodce věc rozhodnout podle rozhodného práva, ${ }^{2}$ tedy použít př́ílušné předpisy lex causae, popř. některá pravidla nestátního

1 Viz např. ustanovení § 25 odst. 2 č. 216/1994 Sb., o rozhodčím řízení a o výkonu rozhodčích nálezů, ve znění pozdějších předpisů.

2 BORN, G. B. International Commercial Arbitration. 2. vyd. Haag: Kluwer Law International, 2014, s. 1997. 
původu, jako např. transnacionální právo mezinárodního obchodu obecně známé pod pojmem lex mercatoria. ${ }^{3}$ Za určitou výjimku lze v tomto ohledu označit rozhodování ex aequo et bono nebo amiable compositeur, což sice nepředstavuje rozhodování striktně na základě pozitivního práva, avšak nijak nenarušuje uvedenou quasi-soudní povahu činnosti rozhodce, jehož mandátem i v těchto př́padech zůstává věc projednat a vydat rozhodnutí o právech a povinnostech stran. Vedle toho je vhodné zmínit, že zmocnění $\mathrm{k}$ tomuto typu rozhodování je $\mathrm{v}$ mezinárodní praxi poměrně ojedinělé. ${ }^{4}$

V této souvislosti pak vyvstává otázka, jakým způsobem se v rozhodčím řízení právní normy použitelné pro meritum věci zjišt’ují a aplikují. Nejde o problém kolizní, tedy o to, který právní rád (nebo jiný soubor pravidel) se použije, ale o následnou otázku, jak se s takto určeným souborem právních norem zachází.

Ve vnitrostátním rozhodčím řízení, které se koná v zemi, v níž mají strany svůj domicil a s níž také souvisí předmět sporu, lze předpokládat, že právo této země bude typicky též právem rozhodným pro meritum sporu. Pochází-li ze stejné země též rozhodci, zjištění obsahu tohoto práva a jeho použití tak nebude činit zvláštní problémy, když pro strany i rozhodce jde o právo tuzemské. V mezinárodním rozhodčím řízení je však situace jiná - rozhodci ani strany nutně nemusí znát rozhodné právo v dané věci. Znalost použitelného práva rozhodcem je pak pro stranu sporu přirozeně jedním z významných faktorů při výběru rozhodce. ${ }^{5}$

Pokud rozhodce použitelné právo nezná, v praxi mezinárodního rozhodčího řízení se předpokládá, že strany samy předloží právní posouzení daného př́ípadu ${ }^{6}$ a prokážou rozhodci obsah rozhodného práva na základě právních textů, judikatury či znaleckých posudků. ${ }^{7}$ Zde však vyvstává otázka, zda je v pravomoci rozhodce zjistit obsah použitelného práva a věc po právní stránce posoudit samostatně anebo zda je v tomto ohledu omezen návrhy stran a prameny práva, na které strany ve svých podáních odkazují. Tento článek si tak klade za cíl nastínit problémy spojené se zacházením s rozhodným právem v mezinárodním rozhodčím řízení, a to především z hlediska obecného vnímání předmětu mandátu rozhodce a jeho mezí. Řešení předmětné otázky v mezinárodní praxi a judikatuře autor rozebírá ve své disertační práci, zde však vzhledem k omezenému rozsahu svůj př́ispěvek věnuje analýze problematiky v teoretické rovině, a to konkrétně z hlediska doktrín, principů a základních institutů rozhodčího rrízení.

3 K tomuto viz např. PAUKNEROVÁ, M. Rozhodči ř́zení ve vztahu k zahraničí - otázky rozhodného práva. Právní rozhledy, 2003, č. 12, s. 587 a násl.; ROZEHNALOVÁ, N. Lex mercatoria a jeho užití v ř́zení před mezinárodními rozhodci. Právní praxe v podnikání, 1999, roč. 8, č. 11, s. 29 a násl.

4 MOSES, M. L. The Principles and Practice of International Commercial Arbitration. Cambridge: Cambridge University Press, 2008, s. 79.

5 KAUFMANN-KOHLER, G. The arbitrator and the law : Does he/she know it? Apply it? How? And a few more questions. In: WIRTH, M. (ed.). Best Practices in International Arbitration. Konference ASA Swiss Arbitration Association dne 27. ledna 2006 v Zürichu, s. 93. Dostupné na: http://archive-ouverte.unige.ch /unige: 30374.

6 KAUFMANN-KOHLER, G. The Governing Law: Fact or Law? - A Transnational Rule on Establishing its Content. In: WIRTH, M. (ed.). Best Practices in International Arbitration, ASA Special Series, č. 26, 2006, s. 84.

7 KNUTS, G. Jura Novit Curia and the Right to be Heard - An Analysis of Recent Case Law. Arbitration International, 2012, vol. 28, no. 4, s. 672. 


\section{ZJIŠTĚNÍ OBSAHU ROZHODNÉHO PRÁVA}

Nezávislé posouzení věci rozhodcem se může objevovat $\mathrm{v}$ různých formách. Pokud jde o zjišt’ování obsahu práva rozhodného pro předmět sporu, zde je nejdř́ve nutné si položit otázku, zda je rozhodce vůbec oprávněn aplikovat a své rozhodnutí odůvodnit na základě právních norem, na které strany ve svých podáních neodkazují. Takovéto jednání může mít za následek především procesní pochybení v podobě upření možnosti stran věc před rozhodcem projednat. ${ }^{8}$ Vzhledem $\mathrm{k}$ tomu, že takováto právní norma bude typicky mít pro jednu stranu sporu pozitivní či negativní důsledky, může být ohrožen jeden ze základních principů vedení rozhodčího řízení, a to princip rovného zacházení se stranami. ${ }^{9}$

Z opačného hlediska si lze opět klást otázku, kam až sahá povinnost rozhodce věc rozhodnout na základě použitelného práva, tedy jestli rozhodce je povinen aplikovat na daný skutkový stav př́ślušné právní normy ex officio, tj. i bez návrhu. Jedno z nejvýznamnějších specifik rozhodčího řízení, tedy zákaz meritorního přezkumu rozhodčího nálezu soudem, alespoň na první pohled evokuje dojem, že nezohlednění právních norem, na které ani strany neodkazují, nemůže mít na platnost ${ }^{10}$ a vykonatelnost rozhodčího nálezu jakýkoli vliv. Rozhodne-li soud, že v rozhodčím řízení měly být aplikovány některé právní normy, jde o věcný přezkum nálezu.

Avšak ne vždy musí jít o problém čistě hmotně-právní povahy. Pokud rozhodčí senát neaplikuje př́slušné právní normy s odůvodněním, že nebyly stranami prokázány, může se jednat i o pochybení procesní, tedy nedostatek potenciálně zakládající důvod pro zrušení či odmítnutí uznání rozhodčího nálezu. ${ }^{11}$ Př́istupy k této otázce se však liší, a to především $\mathrm{v}$ závislosti na tom, zda příslušné lex arbitri zachází s použitelným cizím právem jako s právem nebo jako se skutečností. ${ }^{12}$

Konečně je také možné hovořit o povinnosti rozhodce aplikovat pouze některé normy $\mathrm{v}$ závislosti na jejich povaze. $\mathrm{V}$ zásadě přichází $\mathrm{v}$ úvahu omezení této pravomoci rozhodce na kogentní normy lex causae nebo normy střežící určitý veřejný zájem, tj. typicky imperativní normy třeba i třetích států. ${ }^{13}$ Účelem takovéhoto pojetí povinnosti rozhodce aplikovat př́slušné normy dopadající na daný právní vztah je zajištění souladu $\mathrm{s}$ veřejným pořádkem jiných zemí, a tedy i vykonatelnosti rozhodčího nálezu $\mathrm{v}$ těchto zemích.

\footnotetext{
8 Viz např. čl. V odst. 1 písm. b) Úmluvy o uznání a výkonu cizích rozhodčích nálezů, New York, 10. června 1958 (dále jen „Newyorská úmluva“) nebo čl. 34 odst. 2 písm. a) bod ii) Vzorového zákona UNCITRAL pro mezinárodní obchodní arbitráž z roku 1985, ve znění změn z roku 2006 (dále jen „Zákon UNCITRAL“)

9 Viz čl. 18 Zákona UNCITRAL.

10 Pojem platnosti rozhodčího nálezu autor používá v souvislosti s takovým nálezem, u něhož nejsou dány důvody pro jeho zrušení v zemi, v níž byl vydán.

11 Viz čl. V odst. 1 písm. d) Newyorské úmluvy nebo čl. 34 odst. 2 písm. a) bod iv) Zákona UNCITRAL.

12 CORDERO MOSS, G. Is the Arbitral Tribunal Bound by the Parties' Factual and Legal Pleadings? Stockholm International Arbitration Review, 2006, no. 3, s. 22.

13 Viz MOSES, c. d., s. 81.
} 


\section{NEZÁVISLÉ PRÁVNÍ POSOUZENÍ PŘEDMĚTU SPORU}

Stejně tak nezávislé právní posouzení rozhodce může mít různé formy. Jednak se může jednat o situace, kdy rozhodce nárok sice přizná v rámci žalobního petitu, avšak na základě jiného pravidla/ustanovení. Jako př́klad lze uvést přiznání náhrady škody, která měla vzniknout $\mathrm{v}$ důsledku prodlení prodávajícího, ačkoli kupující náhradu požadoval jako nárok z vad dodaného zboží. ${ }^{14}$ Obdobně se mủže žalobce domáhat určení práva na odstoupení od smlouvy, které rozhodčí senát sice shledá oprávněným, avšak na základě jiného důvodu, než který byl uplatňován žalobcem. Pouhé odlišné právní posouzení, které zůstává $\mathrm{v}$ mezích žalobního petitu, by nemělo být považováno za rozhodnutí ultra petita, tedy překračující pravomoc/mandát rozhodce, ačkoli ani toto neplatí zcela bez výjimek. ${ }^{15}$

Rozdílné právní posouzení věci však může mít za následek tzv. překvapivost rozhodnutí16 a tudíž ohrozit právo stran věc před rozhodci projednat. $Z$ toho důvodu se jeví žádoucím strany vyzvat $\mathrm{k}$ tomu, aby se $\mathrm{k}$ této nové právní otázce vznesené rozhodčím senátem vyjádřily. Má-li se však takové vyjádření pohybovat pouze $\mathrm{v}$ rovině právní argumentace, kterou senát zásadně není vázán, může být nutnost takové výzvy diskutabilní. ${ }^{17} \mathrm{Na}$ druhou stranu je nutné vzít v potaz skutečnost, že v mezinárodním rozhodčím řízení strany (resp. jejich zástupci) stejně jako rozhodci nezř́ídka pochází z různých právních kultur a tudíž jakékoli odlišné právní posouzení věci rozhodčím senátem bude velmi pravděpodobně pro strany a jejich zástupce překvapivé, tudíž v možném rozporu s právem stran věc před rozhodci projednat. ${ }^{18} \mathrm{~V}$ každém př́ípadě vyžaduje-li tato odlišná právní kvalifikace doplnění dokazování nebo zakládá-li se na zcela nových (tj. doposud neuplatněných) pramenech práva, jeví se výzva k vyjádření stran jako žádoucí v zájmu zajištění vykonatelnosti rozhodčího nálezu. ${ }^{19}$

Ještě výraznější intervenci rozhodčího senátu představuje situace, kdy rozhodčí senát dojde $\mathrm{k}$ závěru, že straně náleží, a tudíž by mohl být přiznán nárok, který v řízení neuplatňuje. S takovýmto postupem je spojena řada rizik. Obecně může být přiznání nároku, který nebyl v petitu žalobce uplatněn, považováno za jednání rozhodce ultra

14 CORDERO MOSS, c. d., s. 23-24.

15 LANDOLT, P. Arbitrators' Initiatives to Obtain Factual and Legal Evidence. Arbitration International. The Journal of the London Court of International Arbitration, 2012, vol. 28, no. 2, s. 192.

16 K otázce překvapivosti/nepředvídatelnosti rozhodčího nález viz např.: LEW, J. D. M. Iura Novit Curia and Due Process. Legal Studies Research Paper No. 72/2010, Queen Mary University of London, School of Law, s. 15. Dostupné na http://ssrn.com/abstract=1733531; GILLIS WETTER, J. Procedures for Avoiding Unexpected Legal Issues. In: VAN DEN BERG, A. J. (ed.). Planning Efficient Arbitration Proceedings: The Law Applicable in International Arbitration, ICCA Congress Series, vol. 7, 1996, s. 87-99; MEIER, A. - MCCOUGH, Y. Do Lawyers Always Have to Have the Last Word? Iura Novit Curia and the Right to Be Heard in International Arbitration: an Analysis in View of Recent Swiss Case Law. ASA Bulletin, 2014, vol. 32, no. 3, s. 503; LEVY, L. Jura Novit Curia? The Arbitrator's Discretion in the Application of the Governing Law. Kluwer arbitration blog. Dostupné na: http://kluwerarbitrationblog .com/blog/1009/03/20/jura-novit-curia-the-arbitrator's-discretion-in-theapplication-of-the-governing -law/.

17 CORDERO MOSS, c. d., s. 28.

18 GIOVANNINI, T. International Arbitration and Jura Novit Curia - Towards Harmonization. In: FERNÁNDEZ-BALlATEROS, M. Á. - ARIAS, D. (eds.). Liber Amicorum Bernardo Cremades, Wolters Kluwer España; La Ley, 2010, s. 507.

19 CORDERO MOSS, c. d., s. 28. 
petita a jako takové vést k ohrožení platnosti či vykonatelnosti nálezu. ${ }^{20}$ Nevyrozumí-li rozhodčí senát strany o svém odlišném právním posouzení a nevyzve-li je ke sdělení svého stanoviska, může takový postup vést $\mathrm{k}$ porušení práva stran věc $\mathrm{v}$ řízení projednat. A i pokud senát strany vyzve k vyjádření, zůstává otázkou, zda není takovéto uvedení nového (stranami nevzneseného) nároku samotným rozhodčím senátem do daného řízení v rozporu se zásadou rovnosti zbraní, když fakticky jde o poučení jedné ze stran o jejím hmotně-právním nároku, který v řízení tato strana přitom ani neuplatnila.

Další otázky pak vyvstávají v souvislosti s některými specifickými případy, jako napřr. rozhodčí rízení, v němž participuje pouze žalující strana, tedy kde žalovaná (třeba jen kromě obecného blanketového odmítnutí nároků protistrany) nepředloží rozhodčímu senátu jakékoli právní posouzení věci. Je to opět princip rovnosti zbraní, který $\mathrm{v}$ závislosti na úhlu pohledu může $\mathrm{v}$ takovém př́padě sloužit oběma stranám. $Z$ určitého hlediska může skutečnost, že rozhodčí senát má k dispozici pouze právní argumentaci participující strany, ospravedlňovat nutnost zvýšené aktivity rozhodčího senátu ve smyslu samostatného zjišt'ování použitelných předpisů a nezávislého právního posouzení věci, které může ve výsledku vést $\mathrm{k}$ zamítnutí žaloby např. na základě norem, které sám senát uznal za použitelné, ač na ně žádná ze stran neodkazovala. Na druhou stranu může taková činnost senátu vést $\mathrm{k}$ faktickému suplování role neparticipující strany v rozporování uplatňovaného nároku a ve výsledku tak narušit rovnost stran řízení.

\section{ZÁSADA IURA NOVIT CURIA V ROZHODČÍM ŘÍZENÍ}

Jak bylo demonstrováno výše, problematika zacházení s rozhodným právem v mezinárodním rozhodčím řízení vyvolává množství otázek. Odpovědi na tyto poskytuje jeden ze základních principů kontinentálního civilního řízení definující roli soudce při aplikaci práva pro rozhodnutí ve věci, a to zásada iura novit curia. Význam této zásady, která v překladu zní „soud zná právo“, zřejmě lépe vystihuje pro ni výchozí maxima „,da mihi factum, dabo tibi jus“, tedy „dej mi skutek, právo ti dám já“. Podle tohoto pravidla tak strany poskytnou soudci rozhodné skutkové okolnosti a ten na tento skutkový stav samostatně aplikuje právo, které sám vyhledá. ${ }^{21}$ Nejvýznamnějším důsledkem pak je, že na rozdíl od skutečností, které se po jejich prokázání subsumují pod příslušné právní normy, nemusí strany právo dokazovat. Soud právo zná, a tudíž jej použije z úřrední povinnosti, tedy i bez návrhu stran. Pokud jde o právní posouzení soudu, to je v důsledku zásady iura novit curia nezávislé na právních argumentech stran, které nemohou ani svou dohodou jakkoli omezit to, jak má soud věc právně kvalifikovat. ${ }^{22}$

$\mathrm{V}$ této formě se však v zemích civil law předmětná zásada uplatňuje pouze ve vztahu $\mathrm{k}$ lex fori, tedy právu pro daný soud tuzemskému. Má-li se podle př́slušných kolizních norem použít cizí/zahraniční právo, presumpce „znalosti práva“ je již přirozeně neudr-

20 Viz čl. V odst. 1 písm. c) Newyorské úmluvy nebo čl. 34 odst. 2 písm. a) bod iii) Zákona UNCITRAL.

${ }^{21}$ KÜHN, Z. Iura novit curia: aplikace starého principu v nových podmínkách. Právní rozhledy, 2004, č. 8 , s. 295.

22 OBERHAMMER, P. - DOMEJ, T. Germany, Switzerland and Austria. In: VAN RHEE, C. H. (ed.). European Traditions in Civil Procedure. Antverpy: Intersentia, 2005, s. 303. 
žitelná. Iura novit curia tak dopadá pouze na tuzemské kolizní normy, které představují součást lex fori a jako takové se použijí bez návrhu. Kontinentální právní systémy však i ve vztahu k cizímu právu předpokládají vlastní aktivitu soudce, když soudům ukládají povinnost zjistit a aplikovat právo použitelné na základě kolizní normy ex officio, což je typicky doprovázeno též zacházením s cizím právem jako s právem. Tím se odlišují od systémů anglosaských, kde nejenže kolizní normy nemusí být z úřední povinnosti aplikovány, ale cizí právo se typicky použije jen k návrhu strany, která jeho obsah musí prokázat jako kteroukoli jinou skutečnost. 23

V rozhodčím řízení, kde se lze setkat též s pojmem iura novit arbiter, ${ }^{24}$ plní tato zásada shodnou funkci; vymezuje tedy roli rozhodce a stran ve vztahu k zacházení s právem rozhodným pro meritum sporu. S jistou mírou paušalizace tak lze říct, že zásada iura novit curia ve všech výše uvedených otázkách zjišt'ování použitelného práva a právního posouzení věci v rozhodčím řízení podporuje aktivní př́stup rozhodce. Rozhodce vycházející z této zásady tak má pravomoc samostatně zjišt’ovat obsah použitelného práva a nezávisle na stranách posuzovat předmětný spor. $\mathrm{V}$ krajní podobě (v duchu pravidla ,da mihi factum, dabo tibi jus") by procesní povinností stran bylo pouze tvrdit rozhodné skutečnosti a předložit odpovídající důkazy, zatímco rozhodce by samostatně zjistil obsah rozhodného práva a aplikoval jej na daný skutkový stav. Takový postup je však v praxi mezinárodního rozhodčího řízení velmi těžko představitelný. ${ }^{25}$

Na otázku zacházení s rozhodným právem však praxe mezinárodního rozhodčího řízení stále marně hledá jednoznačnou odpověd'. ${ }^{26}$ Jedním $z$ důvodů je přirozeně skutečnost, že rozhodci (popř. též zástupci stran) pocházející ze zemí civil law či common law mívají o zacházení s rozhodným právem a samotné podstatě svého mandátu různé představy. Vedle toho je vůbec diskutabilní, nakolik mohou či musí rozhodci při zjištování a aplikaci rozhodného práva vycházet z principů ovládající soudní civilní rízení (jako je princip iura novit curia), natož který právní rád je v tomto ohledu relevantní (lex arbitri nebo lex causae). Tyto různé způsoby vnímání mandátu rozhodce se promítají do obecných představ o podstatě rozhodčího řízení, jež představují tzv. doktríny rozhodčího řízení. ${ }^{27}$

23 PAUKNEROVÁ, M. Aktuální otázky používání zahraničního práva v soudním a v rozhodčím řízení. Právník, 2012, roč. 151, č. 12, s. 1277-1278.

24 Viz např. ARROYO, M. Which is the Better Approach to Jura Novit Arbiter - the English or the Swiss? In: MÜllER, Ch. - RIGOZZI, A. (eds.). New Developments in International Commercial Arbitration, Schulthess, 2010, s. 27-54.

25 DIMOLITSA, A. The equivocal power of the arbitrators to introduce ex officio new issues of law. $A S A$ Bulletin, 2009, vol. 27, no. 3, s. 439.

26 KAUFMANN-KOHLER, The arbitrator and the law : Does he/she know it? Apply it? How? And a few more questions, s. 87.

27 WAINCYMER, J. Procedure and Evidence in International Arbitration. Alphen aan den Rijn: Kluwer Law International, 2012, s. 1064. 


\section{IURA NOVIT CUIRA Z HLEDISKA DOKTRÍN ROZHODČÍHO ŘÍZENÍ}

Pojem rozhodčího řízení zahrnuje dva elementární prvky. Prvním z nich je pravomoc rozhodce rozhodnout spor, druhým pak rozhodčí smlouva jako zdroj této pravomoci. ${ }^{28}$ Zdůrazňování jednoho z těchto prvků má za následek posunutí vnímání charakteru rozhodčího ř́zení, které lze rozdělit do kategorií obecně známých jako doktríny rozhodčího řízení. ${ }^{29}$

Základní polaritu těchto př́stupů demonstrují doktríny jurisdikční a smluvní. Teorie jurisdikční chápe rozhodčí řízení jako sporné řízení, v němž rozhodci řeší spor nalézáním práva na základě pravomoci delegované státem. ${ }^{30}$ Jakkoli tedy jurisdikční teorie připouští, že rozhodčí ř́zení může proběhnout na základě dohody stran, ${ }^{31}$ zdůrazňuje, že vedle rozhodčí smlouvy musí rozhodčí řízení jako způsob řešení sporů připouštět př́slušný právní řád. ${ }^{32}$

Doktrína smluvní naopak staví do popředí autonomii stran a jako základ pravomoci rozhodce prezentuje rozhodčí smlouvu. Klasická smluvní teorie dokonce vnímala rozhodce jako zástupce stran, jehož úkolem je zjistit obsah smlouvy hlavní a to následně uvést $\mathrm{v}$ rozhodčím nálezu, který sám představuje smlouvu. ${ }^{33}$ Moderní smluvní teorie od takto extrémní pozice upouští, avšak stále vnímá rozhodči rízení primárně jako institut smluvního práva, který tak podléhá nikoli úpravě civilního procesu, ale autonomii stran. ${ }^{34}$

Jak už její název napovídá, smíšená/hybridní doktrína představuje kompromisní řešení nedostatků jurisdikční a smluvní teorie. Sice uznává, že základním předpokladem pro rozhodčí rízení je rozhodčí smlouva, avšak dodává, že musí být rozeznána právním řádem, který konání rozhodčího řízení připouští a který přiznává rozhodčímu nálezu účinky rozhodnutí soudu. ${ }^{35}$

$\mathrm{V}$ duchu delokalizačních tendencí se $\mathrm{v}$ mezinárodním rozhodčím řízení vyvinula také teorie autonomní. Ta se od všech zbývajících doktrín oproštuje premisou, že rozhodčí ř́zení může existovat nezávisle na jakémkoli pozitivním právním řádu. Právní

28 GAILLARD, E. - SAVAGE, J. (eds.). Fouchard Gaillard Goldman on International Commercial Arbitration, Haag: Kluwer Law International, 1999, s. 11.

29 Z tuzemské literatury viz RŮŽIČKA, K. K otázce právní povahy rozhodčího řízení. Bulletin advokacie, 2003, č. 5, s. 33. BĔLOHLÁVEK, A. - PEZL, T. Postavení rozhodčího řízení v systému ochrany práv a ústavního pořádku České republiky a dalších zemí. Právní rozhledy, 2004, č. 7. ROZEHNALOVÁ, N. Hlavní doktríny ovládající rozhodčí řízení. In Dny práva - 2009-Days of Law. Brno: Masarykova univerzita, 2009. Dostupné na: http://www.law.muni.cz/sborniky/dny prava 2009/files/rozhodci rizeni.html. Ze zahraniční literatury viz: LEW, J. D. M. - MISTELIS, L. A. - KRÖL̄L, S. M. Comparative International Commercial Arbitration. Haag: Kluwer Law International, 2003, s. 74-82. BORN, G. B. International Commercial Arbitration. 2. vyd. Haag: Kluwer Law International, 2014, s. 214-216.

30 BĚLOHLÁVEK, A. J. Zákon o rozhodčím řizení a o výkonu rozhodčích nálezů. Komentár̆. 2. vyd. Praha: C. H. Beck, 2012, s. 26.

31 ROZEHNALOVÁ, N. Rozhodči řizeni v mezinárodním a vnitrostátním obchodním styku. 3. vyd. Praha: Wolters Kluwer ČR, 2013, s. 72.

32 LEW - MISTELIS - KRÖLL, c. d., s. 74-75. BĚLOHLÁVEK - PEZL, c. d., s. 258.

33 BĚLOHLÁVEK, Zákon o rozhodčím ř́zeni a o výkonu rozhodčich nálezů. Komentár̆, s. 23. BĚLOHLÁVEK - PEZL, c. d., s. 257.

34 RŮŽIČKA, c. d., s. 36.

35 LEW - MISTELIS - KRÖLL, c. d., s. 79-80. 
rámec mezinárodního rozhodčího řízení tak utvář́ jeho samotná praxe a nikoli jednotlivé národní právní úpravy. ${ }^{36}$

Z hlediska doktrín rozhodčího řízení lze nahližet též na podstatu mandátu rozhodce a tudíž i jeho př́stup $\mathrm{k}$ zacházení $\mathrm{s}$ rozhodným právem ve smyslu zásady iura novit curia. Jurisdikční pojetí rozhodčího řízení jakožto fóra, $\mathrm{v}$ němž rozhodce nalézá právo a autoritativně rozhoduje o právech a povinnostech stran, na první pohled podporuje aktivní prrístup rozhodce ve vztahu k zacházení s rozhodným právem. Naopak z hlediska smluvní doktríny zdůrazňující autonomii stran se uplatnění zásady iura novit curia, která rozhodci umožňuje věc právně posoudit nad rámec argumentů stran, může jevit jako nežádoucí. Jak však bude demonstrováno níže, uvedené rozlišení není zdaleka tak jednoznačné.

V duchu jurisdikční teorie rozhodčího řízení rozhodce vykonává rozhodovací pravomoc cestou nalézání práva. ${ }^{37}$ Tím však stále není zodpovězena otázka, jakým způsobem má tento proces probíhat, tedy zda má rozhodce nalézat právo pouze v podáních stran, nebo na základě vlastního šetření. V literatuře se sice lze setkat s názorem, že uplatnění principu iura novit curia je vnitřně spjato s jurisdikčním vnímáním rozhodčího řízení, protože v tomto pojetí rozhodce vykonává jakousi quasi-soudní funkci. ${ }^{38}$ Tento postoj však opomíjí skutečnost, že uvedená zásada ovládá civilní soudní řízení pouze v některých právních systémech, a to především zemí kontinentální právní kultury. V anglosaské tradici naopak civilní proces obvykle podléhá projednací zásadě a soud tak vychází především z právní argumentace předložené stranami. S výkonem soudní pravomoci tak není nutně spojen aktivní př́stup soudce, jehož projevem je např́klad právě uplatnění principu iura novit curia. Spočívá-li tak jurisdikční doktrína v přirovnávání soudní a rozhodčí funkce, nelze z ní dovozovat rovněž aktivní prrístup rozhodce. Jurisdikční pojetí rozhodčího řízení pouze zdůrazňuje aspekty nalézání práva a autoritativního rozhodování o právech a povinnostech stran v činnosti rozhodce, neurčuje však tendenci směrem k projednacímu nebo vyšetřovacímu způsobu vedení ŕízení.

Z hlediska smluvní teorie, podle níž rozhodči ǐízení podléhá především autonomii stran, se jakékoli iniciativy rozhodce nad rámec návrhů stran na první pohled jeví jako nežádoucí. Autonomie stran však pouze znamená, že rozhodčí řízení je podřízeno jejich vůli a zájmům. Je tak zcela na stranách, aby se dohodly na rozložení zodpovědnosti za právní kvalifikaci věci a stanovení obsahu rozhodného práva v daném řízení. Pokud strany od rozhodčího řízení očekávají rozhodnutí jejich sporu na základě správné aplikace všech použitelných norem a pokud tak činí v důvěře v rozhodce, jež si pro jejich odbornost zvolily, pak je to právě autonomie stran, co odůvodňuje uplatnění principu iura novit curia $\mathrm{v}$ daném řízení. Smluvní pojetí rozhodčího řízení tak použití tohoto principu nebrání, ačkoli nakonec vždy záleží na očekávání a zájmech stran, o čemž bude blíže pojednáno v následující kapitole ohledně autonomie stran.

Pokud se tedy jedná o pozici zásady iura novit curia, jednotlivé doktríny rozhodčího řízení sice naznačují jisté tendence, avšak otázku uspokojivě nezodpovídají. Vedle toho je nutné mít na paměti, že se jedná pouze o teoretické modely, které sice umožňují nahlí-

\footnotetext{
Tamtéž, s. 81-82.

7 BĚLOHLÁVEK, Zákon o rozhodčím ř́zeni a o výkonu rozhodčich nálezů. Komentár̆, s. 26.

38 WAINCYMER, c. d., s. 1064.
} 
žet na rozhodči ǐízení z různých úhlů pohledu, avšak již ze své podstaty realitu rozhodčího řízení nijak nedefinují. Jurisdikční a smluvní teorie navíc mají tendenci zdůrazňovat některé aspekty rozhodčího řízení a zakrývat jiné, což vede $\mathrm{k}$ jistému zkreslení jeho skutečné povahy. $Z$ toho důvodu je tak při zkoumání kompatibility principu iura novit curia $\mathrm{s}$ rozhodčím řízením nutné vycházet z objektivního posouzení jednotlivých neodlučitelných charakteristik rozhodčího řízení, což je předmětem následujícího výkladu.

\section{AUTONOMIE STRAN}

Základní zásadou, jejíž funkce proplouvá celým procesem od uzavření rozhodčí smlouvy, zahájení rozhodčího řízení až po jeho vedení, je zásada autonomie stran. Autonomie stran, někdy též označovaná jako jeden z pilířu rozhodčího řízení, ${ }^{39}$ má za následek skutečnost, že strany mohou svou dohodou určit rozložení působnosti mezi rozhodcem a stranami rozhodčího řízení při právní kvalifikaci daného sporu a zjištění obsahu použitelných norem. Jinými slovy $\mathrm{v}$ důsledku autonomie stran je $\mathrm{v}$ jejich dispozici, aby rozhodci svou dohodou stanovily, zda a jakým způsobem tento může nad rámec vymezení sporu stranami věc právně posoudit nebo aplikovat právní normy, na něž strany neodkazují.

Z hlediska autonomie stran je nutné zohlednit očekávání stran ve vztahu ke způsobu vedení řízení, tedy včetně použitelnosti pravidla iura novit curia $\mathrm{v}$ mezinárodním rozhodčím řízení. Uzavření rozhodčí smlouvy, stanovení konkrétních parametrů rozhodčího řízení (např. sídlo rozhodčího řízení) a jednání stran v průběhu řízení (např. jmenování rozhodce či způsob, jakým strany prezentují své právní argumenty) totiž mohou být více než nápomocné pro zjištění, jaký př́stup strany k uplatnění zásady iura novit curia $\mathrm{v}$ rozhodčím řízení o jejich sporu zastávají.

Tak například již samotná volba rozhodčího řízení, kterou strany projevují uzavřením rozhodčí smlouvy, může $\mathrm{v}$ obecné rovině indikovat náklonnost těchto stran $\mathrm{k}$ řešení jejich sporů v prostředí, které jim na rozdíl od řízení před soudem poskytuje vyšší míru volnosti, nezávislosti na formálních postupech státních orgánů a rychlejší rozřešení sporu. Jedním z hlavních důvodů, proč podnikatelé a další (třeba i veřejnoprávní) subjekty působící v mezinárodním obchodu volí rozhodčí rízení jako způsob řešení jejich sporů, je snaha o přibližení této procedury obchodnímu prostředí. Rozhodčí řízení pro ně tak představuje jen fórum pro prosazení jejich zájmů v podmínkách, v nichž každodenně operují. Může to být též projevem jisté nedůvěry ve schopnost státně-mocenských orgánů efektivně chránit jejich individuální zájmy. ${ }^{40}$ Autoritativní zásahy rozhodčího senátu do právního rámce sporu v duchu zásady iura novit curia pak dle řady autorů narušují autonomii stran a zpravidla tak vedou ke zkrácení/omezení práva stran věc projednat. ${ }^{41}$

Volba rozhodčího řízení jakožto alternativního fóra pro řešení sporů mezi stranami však může být ve vztahu určení př́stupu stran $\mathrm{k}$ uplatnění zásady iura novit curia

39 ROZEHNALOVÁ, Rozhodči ř́zeni v mezinárodním a vnitrostátním obchodním styku, s. 68.

40 LANDOLT, c. d., s. 200.

41 HOBER, K. Arbitration Involving States. In NEWMAN, L. W. - HILL, R. (eds.) The Leading Arbitrators' Guide to International Arbitration. 2. vyd. Juris Publishing, 2008, s. 669. LANDOLT, c. d., s. 187. 
v řízení o jejich sporu dvojznačná. Na jednu stranu lze v uzavření rozhodčí smlouvy spatřovat preferenci stran ohledně toho, aby identifikace rozhodných právních otázek a použitelných právních norem zůstala v jejich dispozici a vztah mezi stranami byl především rychle a efektivně (třeba i na úkor správnosti rozhodnutí) ${ }^{42}$ stanoven konečným rozhodnutím. Autoři jako např. Landolt, kteří ve volbě rozhodčího řízení stranami spatřují především tuto motivaci, pak také zastávají názor, že rozhodce by ve vztahu k právní kvalifikaci věci neměl zasahovat, pokud toho účelu může být dosaženo samotnými stranami, a že jeho role by tak měla být pouze podpůrná. ${ }^{43}$ Vedle toho však může být volba rozhodčího rrízení dána tím, že strany si cení možnosti zvolit si za rozhodce odborníka na konkrétní právní problematiku vztahující se k předmětu sporu nebo osobu s právní kvalifikací ze země, jejímž právem se řídí daný spor. Zatímco v prvním př́ípadě se volba rozhodčího řízení jeví jako snaha stran minimalizovat samostatnou iniciativu rozhodce, v situaci druhé se naopak jedná o projev zájmu na správném právním posouzení a rozhodnutí věci.

Právě posledně zmíněná okolnost, tedy jmenování rozhodce, může být dalším relevantním faktorem pro zjištění přístupu stran $\mathrm{k}$ uplatnění pravidla iura novit curia. Obdobně jako určení sídla rozhodčího řízení, volba rozhodce ze země kontinentální nebo anglosaské právní kultury může naznačovat, jaký způsob vedení ř́zení strana od rozhodce očekává. Právě v očekávání náleží podstata těchto úvah. Vzhledem k tomu, že rozhodčí řízení je vedeno v zájmu a na náklady stran, rozhodčí senát by měl při vedení řízení (tedy např. při zvažování vlastních iniciativ ve vztahu k právnímu posouzení věci) dbát očekávání těchto stran, které lze mnohdy dovodit z výše uvedených skutečností. Identifikace těchto očekávání/zájmů a jejich zohlednění při vedení řízení je pak projevem respektování autonomie stran. Z tohoto důvodu také řada autorů v odborné literatuře doporučuje, aby rozhodčí senát v co nejranější fázi řízení tyto otázky se stranami projednal a dohodnuté řešení zahrnul např. do ujednání o mandátu rozhodce (tzv. Terms of Reference) nebo procesního usnesení. ${ }^{44}$

\section{RYCHLOST A HOSPODÁRNOST ROZHODČÍHO ŘÍZENÍ}

Rychlost a hospodárnost řízení není zásadou ani nutnou charakteristikou rozhodčího řízení, avšak jedná se o jednu ze standardně uváděných výhod rozhodčího řízení a také důvodů, proč strany volí institut rozhodčího řízení pro řešení jejich sporů. 45 $\mathrm{S}$ ohledem na výše zmíněný význam autonomie stran je tak rovněž nutné zkoumat, zda

\footnotetext{
42 Správností rozhodnutí autor míní soulad rozhodnutí s rozhodným právem, kterého rozhodce dosáhne uplatněním zásady iura novit curia, tedy na základě posouzení použitelných norem nezávisle na právním vymezením věci stranami.

43 LANDOLT, c. d., s. 201.

44 ALBERTI, Ch. P. Iura Novit Curia in International Commercial Arbitration: How Much Justice DoYou Want? In: KRÖLL, S. M. - LOUKAS, A. M. et al. (eds.). International Arbitration and International Commercial Law: Synergy, Convergence and Evolution. Kluwer Law International, 2011, s. 30-31. LANDOLT, c. d., s. 223.

45 ROZEHNALOVÁ, Rozhodči řizení v mezinárodním a vnitrostátním obchodním styku, s. 85.
} 
a jaký může mít uplatnění zásady iura novit curia $\mathrm{v}$ rozhodčím řízení vliv na zájem stran dosáhnout v řízení rychlého a hospodárného řešení jejich sporu.

Provádění vlastního šetření rozhodcem ohledně obsahu použitelných právních norem, uvádění nových právních otázek či ustanovování znalce za účelem jejich objasnění, má přirozené konsekvence v podobě prodloužení délky řízení a zvýšení jeho nákladů. Obdobné platí též pro dodatečná podání stran ohledně nově vyvstanuvších právních otázek, která strany činí na výzvu rozhodce. Vedle toho mohou tyto iniciativy vybudit strany $\mathrm{k}$ tomu, že z (velmi často též oprávněných) obav ze závažnosti otázky vznesené rozhodcem budou třeba i nad rámec jeho výzvy tvrdit další skutečnosti, předkládat nové důkazy a uvádět další právní argumenty, jimiž se rozhodci budou opět muset zabývat, což vše $\mathrm{v}$ souhrnu situaci z hlediska rychlosti a hospodárnosti ř́zení bude jen prohlubovat.

Doplnění právních argumentů a doložení dalších právních norem se navíc rozhodci obvykle vyjeví jako potřebná teprve v průběhu nebo až po ústním jednání, kde např. z výslechů právních znalců vyvstanou nové právní otázky. ${ }^{46}$ Není-li ústní jednání nařízeno, rozhodce obvykle bude schopen identifikovat některé problematické otázky vyžadující doplnění teprve poté, co strany zcela vyloží své právní pozice, což v praxi může představovat třeba i několik výměn jednotlivých podání. Aktivní zásahy rozhodce ve vztahu $\mathrm{k}$ vymezení právního rámce daného sporu tak bude mít vliv na délku trvání řízení prakticky bezvýjimečně.

Stejně tak náklady stran se v důsledku těchto iniciativ rozhodce nevyhnutelně zvýší, at' už se jedná o výlohy na právní zastoupení, náklady na znalce nebo poplatek rozhodci. To platí především tehdy, pokud jsou rozhodci placeni podle hodinové sazby, jako je tomu např́klad u Pravidel LCIA ${ }^{47}$ nebo Pravidel CEPANI. ${ }^{48}$ Nicméně též v př́ipadech, kde se poplatek určuje paušálně podle sazebníku, jako např. dle Pravidel ICC, ${ }^{49}$ rozhodčí soud obvykle bere v potaz zvýšenou časovou náročnost či jiné mimořádné okolnosti a poplatek v návaznosti na to obvykle zvyšuje. ${ }^{50}$

Rozhodce by sice mohl za účelem úspory času a nákladů do věci vstoupit již dř́íve, např. po první výměně podání stran, avšak takový postup přináší řadu rizik. Jednak na začátku řízení rozhodce nemusí mít o věci dostatečnou představu na to, aby byl s to správně vyhodnotit stěžejní právní otázky a použitelné normy. V takto rané fázi řízení může poměrně jednoduše nastat situace, kdy rozhodce na základě zkreslené představy o př́ípadu vyzve strany $\mathrm{k}$ doplnění podání a důkazů ve vztahu k právním otázkám, jež rozhodce v tomto okamžiku vnímá jako zásadní, ale které se ve světle následných podání vyjeví jako podružné. Ve výsledku tyto snahy o urychlení řízení a snížení nákladů budou mít zcela opačný účinek. Tento netrpělivý př́stup rozhodce dále může narušit princip autonomie stran. Jestliže rozhodce již od počátku ř́zení strany pomyslně navádí

46 LANDOLT, c. d., s. 202.

47 Viz bod 2 Řádu o nákladech řízení LCIA - Mezinárodního rozhodčího soudu Londýn ICC (dále jen „Pravidla $L C I A^{*}$ ).

48 Viz bod 1 př́lohy č. 1 Rozhodčích pravidel Belgického centra pro rozhoděí řízení a mediaci (Belgian Center for Arbitration and Mediation).

49 Viz čl. 37 odst. 1 Pravidel pro rozhodči řízení Mezinárodního rozhodčího soudu při ICC (dále jen „Pravidla ICC") a čl. 2 odst. 1 Př́lohy III Pravidel ICC.

50 Viz čl. 37 odst. 2 Pravidel ICC a čl. 2 odst. 2 Př́lohy III Pravidel ICC. 
v tom, jakým směrem by se jejich podání měla ubírat, nebo jim dokonce ukládá omezit svá podání na jím uvedené právní otázky, může takový postup vést ke zkrácení práva stran věc projednat. ${ }^{51}$

V teoretické rovině tak může být vložení primární zodpovědnosti za vymezení právního rámce sporu do rukou rozhodce efektivnějším způsobem vedení řízení. Rozhodce totiž zřídkakdy bude mít zájem na prodloužení doby vedení ř́zení či navýšení jeho nákladů. ${ }^{52}$ Naopak strany ř́zení nebo jejich zástupci k tomu mohou mít řadu důvodů, at' už se jedná o vynakládání nadbytečných hodin práce zástupcem strany za účelem zvýšení jeho odměny nebo jen prosté obstrukční strategie strany řízení. V těchto případech pak mohou strany s cílem ztížit či prodloužit vedení řízení a zahltit jej irelevantními skutkovými tvrzeními, důkazy či právními argumenty. Tyto úkazy přitom představují mnohem významnější riziko pro zachování rychlosti a hospodárnosti (ostatně jakéhokoli kontradiktorního) rrízení než zásahy rozhodujícího subjektu do právní kvalifikace věci. Zatímco rozhodce se k těmto iniciativám obvykle uchyluje jen prŕiležitostně a bez postranních úmyslů, v př́ípadě výše uvedeného jednání stran či jejich zástupců se typicky jedná o systematický postup s cílem prodloužit délku řízení či zvýšit jeho náklady. Přesunutí břemena právní kvalifikace věci na rozhodce pak může tyto neblahé, avšak v praxi nikoli ojedinělé vzorce chování stran a jejich zástupců omezit.

Jak vyplývá z výše uvedeného, rychlosti a hospodárnosti řízení lze zřejmě lépe dosáhnout v řízení vedeném rozhodcem než stranami, jelikož jsou to paradoxně právě strany, kdo může výrazněji narušit průběh řízení. V tomto světle se pak uplatnění principu iura novit curia převážně jeví jako nápomocné rychlosti a hospodárnosti řízení. $\mathrm{Na}$ druhou stranu tento aktivní př́stup rozhodce, který z vlastního podnětu do sporu uvádí nové právní otázky a normy, uvádí pro strany do řízení jistou míru nepředvídatelnosti nejen ohledně právní kvalifikace věci, ale též ve vztahu k výši nákladů řízení. Vzhledem k tomu, že jsou to jen a pouze strany, kdo hradí veškeré náklady rozhodčího ř́zení, je zcela legitimní požadavek, aby měly kontrolu nad tím, jakým způsobem jsou tyto náklady vynaloženy. ${ }^{53}$

\section{ADJUDIKAČNÍ CHARAKTER MANDÁTU ROZHODCE}

Bez ohledu na doktríny rozhodčího řízení a jednotlivé názory na roli rozhodce ve vztahu k aplikaci práva je obecně uznávanou skutečností, že předmět mandátu rozhodce spočívá v rozhodnutí sporu právně závazným způsobem. Role rozhodce tak spočívá v projednání návrhů stran a vydání nestranného rozhodnutí stanovující jejich práva a povinnosti, přičemž právě tento aspekt mandátu rozhodce jej přibližuje k výkonu soudní pravomoci a naopak odlišuje od ostatních forem alternativního řešení sporů. ${ }^{54}$ Jak např. uvedl Nejvyšší soud Velké Británie v roce 2011, mandát rozhodce vyžaduje, aby tento vystupoval nad zájmy stran řízení a jednal v roli jim nadřazeného, nikoli pod-

51 LANDOLT, c. d., s. 203.

52 Tamtéž, s. 203.

53 Tamtéž, s. 203.

54 WAINCYMER, c. d., s. 1997. 
řízeného subjektu..$^{55} \mathrm{I}$ pokud budeme $\mathrm{v}$ duchu smluvní teorie chápat činnost rozhodce jako službu poskytovanou stranám, předmětem takové služby je, jak prŕíznačně podotkl též Soudní dvůr Evropské unie, rozhodnutí sporu mezi dvěma či více stranami, čímž lze činnost rozhodce odlišit od mandátu právních zástupců, kteří zásadně hájí zájmy stran. ${ }^{56}$

Rozhodce se však od soudu liší v řadě významných aspektů. Především není státním orgánem a jeho pravomoc je sice odvozena od státní moci, ale v každém konkrétním př́padě je založena rozhodčí smlouvou, tedy dohodou stran, $v$ jejichž zájmu se rozhodčí ř́zení koná. $Z$ toho důvodu se $\mathrm{v}$ duchu smluvní doktríny často tvrdí, že rozhodce disponuje větší mírou volnosti při rozhodování o prř́slušném sporu, než jak je tomu $\mathrm{v}$ případě rrízení před civilním soudem. ${ }^{57}$ To je očividné jednak v prrípadech, kdy se strany dohodnou, že rozhodce má věc rozhodovat ex aequo et bono nebo jako amiable compositeur, kdy má rozhodce výslovné zmocnění $\mathrm{k}$ rozhodnutí věci dle ekvity nebo je oprávněn upravit účinky použitelných právních norem.

Dále je třeba uvést, že soudce aplikuje právo jakožto představitel státu, vůči němuž tak má zpravidla povinnost vydat rozhodnutí v souladu s platným právem a při zachování jisté kontinuity rozhodování $\mathrm{v}$ rámci daného právního řádu. Tento požadavek pak soudci ve světle zásady iura novit curia umožňuje věc právně posoudit a aplikovat právo bez omezení právní kvalifikací a podáním stran. V rozhodčím řízení se však zpravidla jedná pouze o rozhodnutí jednotlivého sporu mezi danými stranami a nikoli uspokojení zájmu státu na správné aplikaci jeho práva. Rozhodnutí rozhodčího soudu také na rozdíl od soudního rozhodnutí nemá precedenční či obdobný význam pro následující rozhodovací praxi; je pouze rozhodnutím sporu pro konkrétní strany, které navíc obvykle nebývá zveřejněno. ${ }^{58} \mathrm{Z}$ těchto důvodů je existence povinnosti rozhodce dosáhnout při rozhodování jakéhosi objektivního standardu aplikace práva přinejmenším diskutabilní. ${ }^{59}$ Východiska, standard a účel rozhodovací činnosti soudce a rozhodce se tak natolik liší, že aplikaci práva $\mathrm{v}$ soudním a rozhodčím řízení tak lze označit za podobné skutkové podstaty jen s velkými obtížemi a analogie pravidel civilního řízení se tak jeví neudržitelnou.

Analogie funkce rozhodce $\mathrm{k}$ výkonu soudní pravomoci skýtá též poměrně významné praktické nedostatky. Zásada iura novit curia se v civilním soudním řízení tradičně uplatňuje pouze ve vztahu $\mathrm{k}$ lex fori, jež soudci znají a $\mathrm{k}$ jehož aplikaci jsou tak kvalifikovaní a jazykově vybavení. ${ }^{60}$ Naopak mezinárodní rozhodce žádné takové lex fori, které by působilo jako jakýsi výchozí právní rád, podle něhož rozhodce obvykle

55 Rozsudek Nejvyššího soudu Velké Británie ve věci Jivraj v. Hashwani ze dne 27. července 2011, sp. zn. [2011] UKSC 40, odst. 41. Dostupné na: https://www.supremecourt.uk/cases/docs/uksc-2010-0158 -judgment.pdf.

56 Rozsudek Evropského soudního dvora ve věci Bernd von Hoffmann v. Finanzamt Trier ze dne 16. záŕí 1997, sp. zn. C-145/96, odst. 17.

57 MOSES, c. d., s. 78.

58 KAUFMANN-KOHLER, G. Arbitral Precedent: Dream, Necessity, or Excuse? Arbitration International. 2007, roč. 23, s. 359-360.

59 LANDOLT, c. d., s. 185.

60 Ve vztahu k české úpravě v zákoně č. 91/2012 Sb., o mezinárodním právu soukromém, ve znění pozdějších předpisů viz PAUKNEROVÁ, Aktuální otázky používání zahraničního práva v soudním a v rozhodčím ř́zení, s. 1285-1286. 
rozhoduje, $\mathrm{k}$ dispozici nemá - pro rozhodce je každé právo cizí. ${ }^{61}$ Zásada iura novit curia $\mathrm{v}$ soudním řízení tak přesněji znamená, že soud zná své právo, což je pojem pro mezinárodního rozhodce neznámý, tudíž použití tohoto principu v mezinárodním rozhodčím řízení na základě analogie k postupu soudce při aplikaci pro něj tuzemského práva postrádá smysl.

$\mathrm{Na}$ věc lze nahlížet rovněž z právně teoretického a potažmo filosofického hlediska. Argument, že úkolem rozhodce je nalézat právo, vychází z premisy, že existuje jediné správné řešení předmětného sporu odpovídající objektivnímu právu. Zatímco o tomto předpokladu lze polemizovat též v obecné rovině, např. pokud jde o výkon soudnictví, v mezinárodním rozhodčím řízení vyvolává tato premisa mnohem významnější pochyby. Rozhodci, strany a jejich zástupci mnohdy mají v důsledku odlišného původu zcela rozdílné, přitom však hluboko zakořeněné představy o správném řešení různých právních otázek. V tomto prostředí neustálého střetu právních kultur je přirozeně představa o jediném a objektivně správném řešení jednotlivých právních otázek značně relativizována. S odkazem na tyto úvahy o „postmoderni“" povaze mezinárodního rozhodčího řízení také někteří autoři tvrdí, že správného řešení sporu v mezinárodním rozhodčím řízení lze zřejmě nejlépe dosáhnout dialektickou metodou, tedy poskytnutím prostoru stranám pro stanovení právního rámce sporu bez vnějších zásahů rozhodce. ${ }^{62}$

\section{ZÁVĚR}

Odborná literatura se $\mathrm{v}$ tomto ohledu prakticky bezvýjimečně shoduje pouze na jediné věci, a to že rozhodce má oprávnění jemu předložený spor právně posoudit samostatně, tedy bez omezení argumenty stran, a z vlastního podnětu zjištovat obsah použitelného práva. Dokonce i autoři, kteří v duchu smluvní doktríny a s důrazem na zásadu autonomie stran rozhodčího řízení použití principu iura novit curia v mezinárodním rozhodčím řízení kritizují, uznávají, že rozhodce může věc posuzovat nezávisle na podáních stran. ${ }^{63}$ Rozložení působnosti mezi rozhodcem a stranami rozhodčího řízení při právní kvalifikaci daného sporu a zjištění obsahu použitelných norem je totiž otázkou vedení řízení, které zpravidla spadá pod diskreci rozhodce. To ostatně dokládají některé národní úpravy lex arbitri ${ }^{64}$ nebo též řády rozhodčích soudů, ${ }^{65}$ které obsahují výslovné zmocnění rozhodce $\mathrm{k}$ tomu, aby $\mathrm{v}$ rámci vedení rízení stanovil, zda a jakým způsobem může rozhodce nezávisle na stranách věc právně posoudit a z vlastního podnětu stanovit obsah použitelných norem. S odkazem na tato a obdobná ustanovení o vedení rozhodčího řízení se pak v literatuře dovozuje, že právě pravomoc rozhodce vést řízení dle svého uvážení implikuje jeho oprávnění jednat podle zásady

61 GAILLARD - SAVAGE, c. d., s. 692, marg. 1263.

62 LANDOLT, c. d., s. 201.

63 LANDOLT, c. d., s. 189-190.

64 Viz $§ 34$ odst. 2 písm. g) Arbitration Act 1996, anglický zákon o rozhodčím řízení z roku 1996, ve znění pozdějších předpisů.

65 Srov. velmi obdobné znění čl. 22 odst. 1 písm. c) Pravidel LCIA. 
iura novit curia $\mathrm{v}$ rozhodčím řízení. ${ }^{66}$ Rozhodce je ,pánem ř́zeni" ${ }^{\text {“67 }}$ a jako takový je oprávněn posoudit jemu předložený spor nezávisle a z vlastního podnětu zjištovat obsah použitelného práva.

Na druhou stranu se velmi často uvádí, že rozhodce by se měl uchylovat k těmto iniciativám podpůrně, tedy pouze $\mathrm{v}$ prŕpadech, kdy podání stran $\mathrm{z}$ různých důvodů nejsou $\mathrm{v}$ tomto ohledu dostačující. ${ }^{68}$ To je ostatně převažujícím názorem v odborné literatuře ${ }^{69}$ nebo též např́iklad ve Zprávě Sdružení pro mezinárodní právo z roku $2008,{ }^{70}$ podle nichž v současné praxi mezinárodního rozhodčího rrízení spočívá zodpovědnost za vymezení právního rámce sporu a použitelných pravidel primárně na stranách.$^{71}$ Hlavním důvodem tohoto př́stupu je význam zásady autonomie vůle a také předvídatelnost vedení rozhodčího řízení. 72 Strany tak mají tzv. ,primárni" nebo též „,hlavni" zodpovědnost za určení právního rámce sporu a prokázání obsahu použitelného práva. Tím je míněno, že rozhodce má $\mathrm{v}$ tomto směru rovněž jisté pravomoci a $\mathrm{v}$ některých př́ípadech tato iniciativa nemusí být ponechána pouze na stranách. To lze ilustrovat na vzorové úpravě otázky aplikace práva v rozhodčím ř́zení vypracované profesorkou Kaufmann-Kohler, která ji sama označuje za spojení odlišných civilně-procesních přístupů:

„Strany prokážou obsah rozhodného práva ve věci. Rozhodči senát je oprávněn, avšak nikoli povinen provést vlastni šetřeni za účelem stanoveni obsahu rozhodného práva ve věci. Vykoná-li rozhodči senát tuto pravomoc, poskytne stranám možnost se vyjádřit $k$ výsledkuim jeho šetření.

Neni-li obsah rozhodného práva prokázán ve vztahu ke konkrétni otázce, rozhodči senát je oprávněn v této otázce použit jakékoli normy, které považuje za vhodné."“73

Tento návrh se zabývá těmi základními a výše vznesenými otázkami v souvislosti s uplatněním zásady iura novit curia. Jednak zakotvuje, že břemeno stanovení rozhodných právních otázek a použitelných norem spočívá zásadně na stranách. Rozhodčí senát do právního rámce daného sporu může zasahovat, avšak není to jeho povinností. Stejné zřejmě platí též pro případ, kdy se obě strany či jedna z nich dostatečně nevyjádří

66 DIMOLITSA, c. d., s. 426-427.

67 LANDOLT, c. d., s. 189-190.

68 Tamtéž, s. 201-202.

69 ALBERTI, In: KRÖLL-LOUKA(eds.), c. d., s. 28. LANDOLT, c. d., s. 198. POUDRET, J. F. - BESSON, S. Comparative Law of International Arbitration. 2. vyd. London: Sweet \& Maxwell, 2007, s. 476.

70 Závěrečná zpráva Sdružení pro mezinárodní právo ke zjišt’ování obsahu použitelného práva v mezinárodním obchodním rozhodčím řízení (Ascertaining the Contents of the Applicable Law in International Commercial Arbitration: Final Report, International Law Association), Rio de Janeiro, 2008. Dostupné v elektronické formě na: http://www.ila-hq.org/en/committees/index.cfm/cid/19.

71 Viz např. KURKELA, M. Jura Novit Curia' and the Burden of Education in International Arbitration A Nordic Perspective. ASA Bulletin, 2003, vol. 21, no. 3, s. 495.

72 LANDOLT, c. d., s. 199.

73 V původním znění (cit.): „The parties shall establish the content of the law applicable to the merits. The arbitral tribunal shall have the power, but not the obligation, to conduct its own research to establish such content. If it makes use of such power, the tribunal shall give the parties an opportunity to comment on the results of the tribunal's research. If the content of the applicable law is not established with respect to a specific issue, the arbitral tribunal is empowered to apply to such issue any rule of law it deems appropriate." KAUFMANN-KOHLER, The Governing Law: Fact or Law? - A Transnational Rule on Establishing its Content, s. 84. 
k určité otázce a kdy tak „obsah rozhodného práva [neni] prokázán ve vztahu ke konkrétni otázce“. Jediná povinnost rozhodce spočívá v situaci, kdy se rozhodne z vlastní iniciativy provést šeření za účelem stanovení obsahu rozhodného práva; pak je povinen poskytnout stranám možnost se vyjádřit k výsledkům jeho šetření.

Posledně zmiňovaným ustanovením tak návrh sleduje ochranu procesních práv stran řízení, tj. především práva na projednání věci a zásady rovnosti zbraní, a tedy také zajištění platnosti a vykonatelnosti rozhodčího nálezu. Důraz na povinnost rozhodce poskytnout stranám možnost vyjádřit se $\mathrm{k}$ jeho vlastnímu šetření ohledně rozhodného práva a právního posouzení věci se zdá být prakticky jediným konkrétním imperativem, jejž lze z hlediska základních principů rozhodčího rrízení dovodit. To ostatně dokládá též skutečnost, že se jedná o snad jedinou otázku, ohledně níž panuje v odborné literatuře takřka bezvýjimečně shoda.

Pokud se však jedná o konkrétní rozložení odpovědnosti za právní posouzení věci a zjištění obsahu rozhodného práva mezi stranami a rozhodčím senátem, je jistá vágnost návrhu profesorky Kaufmann-Kohler naopak dokladem o tom, že obsah a podstata mandátu rozhodce jsou dodnes velmi nejasnými pojmy. Diskuze o této otázce totiž naráží na střet právních kultur, různá a často těžko předvídatelná očekávání stran a konečně také osobní př́stup rozhodců ke své roli a rozhodčímu řízení jako takovému. Za účelem prevence možných rizik z tohoto vyplývajících tak lze pouze apelovat na obezřetnost rozhodců a doporučit, aby tyto otázky v řízení co nejdříve se stranami projednali a řešení otázky stanovili v ujednání o mandátu rozhodce nebo procesním usnesení.

Mgr. František Halfar

Právnická fakulta Univerzity Karlovy

frantisek.halfar@gmail.com 